\title{
Erratum to: Abuse victimization and risk of breast cancer in the Black Women's Health Study
}

\author{
Lauren A. Wise $\cdot$ Julie R. Palmer $\cdot$ Deborah A. Boggs •
}

Lucile L. Adams-Campbell $\cdot$ Lynn Rosenberg

Published online: 15 May 2011

(C) Springer Science+Business Media B.V. 2011

Erratum to: Cancer Causes Control (2011) 22:659-669 DOI 10.1007/s10552-011-9738-3

The correct title of this article is "Abuse victimization and risk of breast cancer in the Black Women's Health Study."
In Table 4, the confidence interval for "intermediate physical abuse frequency" should read: "(0.91-2.43)".

The online version of the original article can be found under doi:10.1007/s10552-011-9738-3.

L. A. Wise $(\bowtie)$ J. R. Palmer · D. A. Boggs · L. Rosenberg Slone Epidemiology Center, Boston University, 1010

Commonwealth Avenue, Boston, MA 02215, USA

e-mail: 1wise@bu.edu

L. L. Adams-Campbell

Lombardi Comprehensive Cancer Center, Georgetown

University, Washington, DC 20057, USA 